\title{
Employee Poaching within the Framwork of Nigerian Work Organziations: An Exposition
}

\author{
Okafor, Lawrence Chima Ph.D \\ Department of Business Management, Ebonyi State University, Abakaliki, Nigeria \\ chiedozieuzom@yahoo.com
}

\begin{abstract}
There is increasing concern regarding the practice of employee poaching by banks and ICT firms in Nigeria. This paper titled "Employee Poaching within the Framework of Nigerian work organizations": an exposition; examines the concept and logic of employee poaching and its likely negative consequences. The correlates of employee poaching (EP) visa-vis Human capital Development (HCD), Succession Management $(S M)$, and Organization Culture (DC) are also investigated. The questionnaire formed the chief instrument for data gathering. Responses of respondents (analyzed using PPMC), supplemented with comments and opinions of "elite interview" show amongst others that employee poaching is inversely related to HCD (- 0.16), that practices and philosophy of employee poaching are opposed to the ideals and requirements of Succession Management (SM). However, EP practices may (at least in the short run) be beneficial to organizations with stagnant culture as it can serve as the needed tonic to shake things up. Therefore, organizations are advised to tread with caution before adopting employee poaching as a recruitment option.
\end{abstract}

Keywords: Employee Poaching, Human Capital, Succession Management, Organization culture.

\section{Introduction/Statement of Problem}

Today, organization theorists, managers and human resource experts are in agreement as to the centrality and criticality of the human element to the success of any enterprise. To this end, mechanistic approaches to the management of employees at work are giving way to more humane and systematic orientation to the employment, retention, and use of workers in modern day organizations. In the main, every organization strives to attain its goals through the adoption of diverse policies and strategies. However, the strategies adopted by organizations differ with each adopted strategy and philosophy having (sometimes, unanticipated) benefits and consequences.

Resources availability, management philosophy and orientation, legal requirements etc, are known to have influenced and determined the type and extent of deployment of strategies. While there is the agreement as to the place of the human resource in the life of organizations, there seem to be considerable disagreement as to what is the "best" strategy for the recruitment and management of staff of organizations.

One strategy cum policy that has generated high level of debate or concern is the poaching strategy. To some persons, the poaching strategy represents attempts to fully maximize the skills and expertise of employees, to others, it is not only unethical, but is indicative of an organization refusal to embark on a conscious journey to management and organizational development. Either way, the strategy like many others, may offer some benefits while presenting some challenges. Against the backdrop of an increasing number of litigations involving "post-employment" in the last five years, the practice of poaching demands an exposition.

\section{OBJECTIVE OF THE STUDY}

The paper is an exposition of the poaching strategy as adopted and deployed by organizations. Drawing inferences from the banking, ICT, and other service oriented organizations, the paper takes a look at the poaching strategy - its likely benefits and observed limitations. Specifically, the paper:

i) Explores the concepts, meaning of and justification for the practice of employee poaching.

ii) Examines the effects and implications of employee poaching on: 
a) Human capital development

b) Management succession and

c) Organization culture - with the hope that managers be better informed and guided before showing preference for this approach to manpower hiring.

\section{Theoretical and Conceptual Framework}

From the practical point of view, it is Herculean to anchor the practice of employee poaching on a single theoretical foundation. This is due to the fact that the variables that bear on and/or re-inforced by employee poaching are always likely multi-faceted. However, for the purpose of academic treaties, we adopt in this study, the eclectic model, drawing largely from the games theory as well as the efficiency wage theory.

Within the domain of psychology, it is called the theory of social situations but it is more popularly known as game theory in the management sciences. Game theory, is the science of strategy that seek to determine the steps and actions that players (organizations) should take to secure the best outcomes for themselves in a wide array of games (Avinash and Naebuff, 2014). The game theory is believed to have been pioneered through the works of Neumann, J.U. (Levine, 2014) with emphasis on strategic decision making especially in conflict and competitive situations, with final outcomes of the game being products of or influenced by strategies chosen by the participants.

Ewurum (2013) appropriately captures the essence and assumptions of game theory to state among others that:

Game theory is a body of knowledge that deals with decision making situations when two or more intelligent and rational opponents (organizations) are involved under conditions of conflict or competition... It is assumed that each player (organization) is capable of making independent and rational decisions and that each player is active.

With focus on the zero-summed game variant, where the loss of one organization is equal to the gain of another, it is conceivable that the gains of say organization A (through the auspices of employee poaching e.g. securing the services of experienced staff, high productivity) is equal to the loss of organization B (loss of expertise, low or declining productivity, divulgence of organization secret). Therefore, since the expectation of each player (organization) is to secure the best of advantages (payoffs), it follows that each organization will deploy the strategies that are likely to confer greater advantages to it.

The second theoretical plank upon which this study is rested is efficiency wage theory which in the opinion of Armstrong (2005) is adopted by those who feel that they are market leaders. Efficiency wage theory proposes that a firm will pay more than the prevailing market price to their employees, premised on the assumption that high level of pay will result in increasing productivity with possible added advantages of attracting better candidates and motivating superior performance. Also known as the "economy of high wages", efficiency wage theory presupposes that workers who are paid far and above their market value rate, may feel that they are being fairly treated with a possible reduction in the rate of employee turnover.

Taken together and in relation to Employee Poaching, some of the deductions from these theories are that organizations compete for limited resources including qualitative and skillful employees as such, any organization is capable of deploying and is free to deploy the most lethal of its strategy to secure maximum advantages. One of such policy/strategy is to poach from rival organization/competitors who in turn may deploy countervailing measure/strategy as may not have been envisioned. Conventionally, organization that want to raid another's' employee(s) are usually willing to make higher and more attractive offers which rhymes with the postulation of efficiency wage theory. To the extent also that the gains made by one organization is equal to the loss of another, we find a comforting justification in adopting these theories for the purposes of our investigation.

Meanwhile, Employee Poaching (EP), has been described using different terminologies. EP, referred to variously as lateral hiring, talent leaching, talent poaching, predatory hiring, employee raiding etc takes place when an organization hires an employee from a competitor. EP is also considered as the art of luring good employee(s) away sometimes from your competitors, by conveying while your organization is better that the current employer. Conventionally, the target of the hirer is not the 
physical attributes of the employee(s) but the ideas, skills and expertise, which sometimes are used in secret and dishonest ways. Today, EP is a fact of organization life, commonly associated however, with small businesses and particularly in high growth, specialized and technology industries. Trade secrets, goodwill, confidential reports have all become victims of employee poaching (Doyle, 2012).

Within the framework of the Nigeria work environments, the deregulation of the banking industry in the 1990s saw the emergence of new generation banks, which sought to gain the services of experienced staff to run their operations. Similarly, bourgeoning needs and deployment of ICT by many different and diverse organizations with limited employee expertise in those areas, demanded an approach to employee hiring that will deliver the goods. This rhymes with a Central Bank of Nigeria (CBN, 2011) circular that the shortage of experienced personnel within the banking industry became more acute, part of the consequences is that banks engaged in all sorts of strategy to attract talented staff from rival institutions. Simply put, there came to be an intensification of employee poaching.

Meanwhile, there is considerable disagreement as to the appropriateness or otherwise of employee poaching. Proponents of employee poaching practice (Hannal, 1997, Leigh, 2005) to name only the se are of the opinion that where no legal restrictions exist, employee poaching should be encouraged. Among the many justification of the practice are that employee poaching.

a) Produces high performance as it enables society to put assets to their best use i.e. it is anchored on the logic that it provides a way for human capacity to flow most efficiently to places it is needed, helping drive economic growth.

b) Employee Poaching may mean bringing on someone who already knows your industry, your size and who can bring valuable knowledge and insights and customer to you. To that extent Employee Poaching

- Saves recruitment, selection, induction and training costs, is the easiest way of securing people as well as a means of eliminating close competitors who share the same views regarding service delivery

- Can help develop an industry especially when the economy is strong, can lead to anti-poaching agreements resulting in company's associating/relating within the industry, and that poaching can make managers to be competitive in terms of pay benefits and other matters relating to employment.

Other benefits of EP chronicled by Sarah, (2010), Doyle, (2012) and as reproduced by Nkanor (2014) include:-

- It helps you acquire competitive intelligence about other firms.

- New hires can help you identify other potential candidates to poach from their firm.

- The new ideas that applicants and new hires bring in stimulate the thinking of others.

- New hires ask - why we do things that way so we are forced to re-think the way we do think.

- It helps out employees on the edge because they know they must compete against outsiders for jobs.

- Outside hires don't have political alliances already set up. This can help them implement new ideas without the-baggage of past political battles.

- It allows other firms to train and weed out the turkey so we can hire the cream of the crop. As a result, it can lower training cost(s).

- In a stagnant culture, - outsiders might help shake things up and help us evolve our culture.

In contrast however, Okezie (2011), proposes the adoption of bonding as a counter measure to employee poaching (bonding agreement demand that a staff(s) be made to work a period before he/she can leave the organization, therefore, bonding are means by which an employer seeks to protect against the possibility of employee poaching) (www.google.com.ng). To him as to many others, "if a company spends time and money in training a staff and paying him good salary, then it will be good for such a staff to work for the bank to justify the training and capacity development." 
Other possible consequences of employee poaching listed in mainstream literature on the concept include:

- Where not checked, EP can be injurious to the operations of the organization that suffers from the brain drain (victim) - for it has to contend with the additional burden of recruiting and re-training a new staff.

- Persistence adherence and employment of the poaching strategy can lead to reluctance on the part of the organization to embark on further training, therefore, relegating capacity building to the background as well as likely consequences of abandonment of development initiatives.

- Still on the side of the sad comments on EP are - outside hires weaken the corporate culture, external hires option has a longer adjustment period, starting salaries of outside hires may cost internal equity issues and eventually increases in all salaries, the turnover rate for external hires is almost always higher than internal promotions and that large scale external hires might yet mean future lay-offs (Nkano, 2014). In addition, E.P. may and do create ethical and legal issues.

A gloss over the arguments for and against Employee Poaching shows that most of the comments/positions relate to cost implication, divulgence of information and productivity concerns. Especially as it relates to many organizations in the developing countries of the world - Nigeria inclusive - the practice of employee poaching is yet to be explored fully as it pertains human capital development, managerial succession and organization culture.

Armstrong, (2005) sees human capital as human ability whether innate or acquired attributes whose values can be augmented through the auspice of development investments. This tally with Beckers (1993) submissions on human capital as been similar to "physical means of production" whose value can be improved on via education, training etc. Human capital is not only a means of production, it is sub suitable however, may not be "transferable". Therefore, human capital is the cumulative total of the talents and skills appropriate to the interests of the enterprise, of its employees and determines the ability of an organization to accomplish its mission. It is in recognition of the place and import of appropriate skilled employees as assets to the organization, that efforts are consciously made at different times and places to add value or to improve on the skills and competencies of employees(s) through human capital training and development initiatives/programmes.

These postulations as to the importance of human capital do not say or depict relationship between employee poaching and human capital development. It is however conceivable that organizations that are in a hurry to acquire the best of experienced personnel, may not have recourse to the needed patience, pain and endurance usually associated with human capital development initiatives, efforts and programmes.

Regarding managerial succession, the Cambridge Business English Dictionary (2015) simply states that it is the planning of how to replace a manager of a company or organization. In the opinion of Caudron and Rothwell (1999),

Succession management is a deliberate and systematic effort by an organization to develop intellectual and knowledge capital for the future and to encourage individual advancement so as to ensure the identification, development and long-term retention of talented individuals.

By inference therefore, Succession Management is in close neighborhood with Management Development in that both seek to equip managers to be able to face the challenges of tomorrow. Therefore, part of the goals of succession management is to match an organization's current competencies and capabilities to its future needed competencies and capabilities (John, 2005). Part of the requirements for succession management according to Drucker (1985) is that Chief Executive Officers (C.E.Os), should surround themselves with innovative and intelligent individuals who will balance their strength against their weaknesses and through this process, the C.E.O in any given organization can determine the individual(s) who can be subjected to training/development for future service delivery, management and organization of the enterprise.

Therefore, where well articulated and implemented, succession management helps to form the basis for employee career path, clarifies development plans, specifies advancement requirements for employees and reduces talent turnover. These intended benefits notwithstanding, every succession management efforts involves: 
- Identification of talents/individuals for development programme. This will entail asking the questions who should be chosen, why these persons and not others, what antecedents or previous experiences have guided our decision and the like?

- Grooming - this will entail conscious development efforts as evidenced in policy formulation and implementation, training and development programmes.

- Handing/Taking over-gradual/piece-meal disengagement from certain activities/functions of the businesses and the assignment of same to successors. Included in this phase are the performance of "oversight" functions, providing guidance, supervision and counseling services; as well as the control of emotions usually associated with "quitting"/leaving an enterprise that may have taken decades to establish and run. From the foregoing it is deciphered that succession management conventionally should involve series of activities and programmes which demand time for it to be articulated, planned and implemented, so that in part, associated emotional consequences can be controlled.

On the other hand, organization culture is said to be a wide and multi-dimensional concept, considered significant in understanding organization dynamics in all its richness and variation. Organizational culture is central to organizational functioning (Smiricich, 1985) and is conceptualized as an aggregation of attitudes, values, norms, style, consumption and general world view of life (Udu, 2010). Conventionally, culture is divided into two major aspects namely: material (i.e. those aspects of culture that are overt and explicit e.g. products of industry, technology, artifacts etc) and nonmaterial culture (usually consisting of the knowledge underlying philosophy, attitudes, values etc) shared and transmitted in an organization.

Amongst others, Scheins' (2004) model provides an insight into how organization culture can be analyzed. To him, organization culture exists in "layers". While the first level reveal attributes that can be seen, felt and heard by the un-initiated, the next level deals with value of the members obtained through administration of questionnaire. In the third and deepest level are to be found organization tacit assumptions. As insightful as these submissions are, the model did not indicate the impact of culture on a wide array of organization performance, growth and stability variables.

From the 1950s when survey studies sought to empirically test the culture - performance link (Wilderom, Glunk and Maslowaski, 2000), there has been considerable growth in the attempt to statistically and empirically relate organization culture to performance indices, performance motivators, and behaviour of organizational participant as typified by the works of Lim (1995), Alvesson (2002) and Udu (2010)). Nonetheless, these efforts and attempts failed to specifically address the issue of organization culture and employee poaching strategy especially as they relate to organizational continuity, commitment and employee assumptions and perception.

\section{Methodology}

The questionnaire formed the chief instrument for collection of data. However, results of analysis of respondents responses were supplemented with views as expressed by those interviewed. A total of one hundred and eighty five (185) copies of questionnaire were sent out, with a return rate of $88 \%$ (i.e. one sixty two (162) were returned and subsequently used for analysis). The questionnaire, arranged into four (4) sections, contained questions relating to respondents opinions and preferences regarding employee poaching strategy and aspects of organization culture, organization human capital development and organization succession management efforts.

The tripartite goals of construct, content, and face validity of the research questionnaire where achieved through the inputs and criticisms of management scientists and experts in organization theory and design. A consistency value of $\mathrm{R}=086$ was obtained through correlational analysis.

\section{FINDINGS AND DISCUSSION}

Analyses of the responses to the questionnaire items together with the comments of those interviewed show that:

- There is an inverse relationship between employee poaching and human capital development with a correlation co-efficient of -0.16 . This is in line with Nkanor's (2014) submission that persistent adherence to the employment of employee poaching as a strategy do lead to reluctance on the part of an organization to embark on conscious efforts aimed at training and development of staff. It is 
part of the submission of this paper that organization that hurry to secure the services of experienced staff from a rival firm may be lacking in the needed patience and endurance associated with human capital development initiatives. The implication is that organizations that are reluctant or ambivalent visa-vis the improvement of skills and competencies of its employees, may in the long run find it difficult to accomplish its mission.

- Employee Poaching practices and philosophies are opposed to the ideals and requirements of succession management. Observable evidence and experiences of organizations surveyed, reveal that the practice of snatching employees from competitors do not show considerable concern to the psychological dispositions of those involved and the time spent by the victimized organizations in the training and development of the employee(s). Again, little concern is given to the possibility that the employee being sought after today, may be the target of another form tomorrow, therefore, succession management efforts are not sufficiently entrenched, with a proposition that the realization of the goals of management succession are made more elusive.

- With reference to stagnant cultures as Doyle (2012) choose to describe it, employee poaching may provide the needed tonic to shake things up. New ideas may be introduced with the potency of revolutionizing work designs and processes to the advantage of the organization. However, nonmaterial aspects of organization culture especially as they relate to values, vision and philosophy may have to bear considerable harm occasioned by the practice of employee poaching - A reinforcement of the position that "in the long-run, we are all dead."

\section{REFERENCES}

Armstrong, M. (2005). A Handbook of Human Resources Management Practice. $9^{\text {th }}$ edition. London: Kogan page.

Alvesson, M. (2002). Understanding Organizational Culture. London: Sage Publication.

Avinsah, K. and Nalebuff, B. (2014). The Concise Encyclopedia of Economics:. www.econ/ib.org/ Liberary retrieved June, $14^{\text {th }} 2014$.

Becker, G. S. (1993). Human Capital: A theoretical and Empirical Analysis, with special Reference to Education. $3^{\text {rd }}$ edition. Chicago: University of Chicago Press.

Cambridge Business English Dictionary (2015). www.goggle.come/m?

Caudron, N. and Rothwell, E. (1999). Introduction to Human Resource Management. Lagos: Onimonode Press.

Central Bank of Nigeria (2011). Central Bank of Nigeria. Economic and Financial Reviews Vol. 16(4). Abuja - Nigeria.

Doyle, A. (2012). Employee Poaching. www.goggle.com.ng. Retrieved 14 ${ }^{\text {th }}$ March, 2014.

Drucker, P. F. (1985). Rudiments of Human Resource Management in Eze, F. C. (2002). Human Resources Management in Nigeria. The Key Components. Enugu: Mckanand Publications.

Ewurum, U. J. F. (2013). Module on Analytical Techniques in Business. Unpublished, Unviersity of Nigeria, Nsukka.

Hannal, B. E. (1997). To Hire or not Hiring. What Silicon Valley Coys should know about Hiring Competitors' Employees. Hasting Law Journal Vol. 48(5), 98-116.

Igbafem, M. L. (2003). Small Scale Enterprises: Issues, Challenges, and Problems. Lagos: Joga Press.

John, J. (2005). Issues and Perspectives in Small and Medium Enterprises. Journal of Society and Development Vol. 2(3) 21-33.

Levine, D. K. (2014). Economic and Game Theory. What is game theory? Levine.sscnet. UCLA.edu/general. Accessed March, 2014.

Leigh, A. (2005). The Role of Equity in Employment Non-Completion Cases. American Business Law Journal Vol. 4(2) 16-33.

Lim, B. (1995). Examining the organizational culture and organizational Performance Link. Leadership and Organization Development Journal Vol. 16(5), 16-21.

Nkanor, S. Y. (2014). Arguments for and Against employee poaching. Paper presented to the department of Business Management, EBSU in fulfillment of the requirements of the PG School.

Okezie, N. (2011). Bonding is the Answer. An address by the Chairman, Stockholders Association of Nigeria, Lagos as part of the AGM. 
Sarah, E. N. (2010). "How to master the Art of Poaching employees" www.inc.com. Retrieved $17 / 5 / 2014$.

Schein, E. H. (2004). Organizational Culture and Leadership. $2^{\text {nd }}$ Ed. San Franciscd: Jossey- Bas.

Smiricich, L. (1985). Is the concept of culture a paradigm for understanding organizations and ourselves. Beverly Hills: Sage Publications.

Udu, A. A. (2010). Influence of Organizational Culture on the Performance of University Academics: A study of the South-East, Nigeria. Unpublished Ph.D Thesis submitted to the Department of Business Management, Ebonyi State University.

Wilderom, C. P. etal (2000). Organizational culture as a predictor of organizational performance. Handbook of organizational culture and climate. Thousand Oaks: Sage Publications.

\section{AUTHOR'S BIOGRAPHY}

My name is Okafor, Lawrence, Chima. Currently, I am in the employ of Ebonyi State University Abakaliki, substancively of the department of Business Management. My research interest areas include policy and industrial studies, organizational behavior, and general management. 